was significantly higher than in groups $1,2(p<0,01$ and $p<0,04$ accordingly) at the end of the study.

Conclusion: Mean values of EScSG-Al score associated with and were accompanied by progression pulmonary alterations in pts SSc so EScSGAl score can be used as valuable tool for long-term follow-up studies.

Disclosure of Interests: None declared

DOI: 10.1136/annrheumdis-2019-eular.6818

\section{AB0218 CORRELATION BETWEEN IMMUNOLOGICAL PARAMETERS AND PULMONARY FUNCTION PARAMETERS IN THE PATIENTS WITH SSC AND ILD OVER 5 YEARFOLLOW UP STUDY}

Olga Ovsyannikova, Lidia P. Ananyeva, Olga Koneva, Liudmila Garzanova, Mayya Starovoytova, Oxana Desinova. V.A. Nasonova Research Institute of Rheumatology, laboratory of microcirculation and inflammation, Moscow, Russian Federation

Background: Interstitial lung disease (ILD) is related to specific radiographic features in lung imaging and/or the presence of restrictive disorders in pulmonary function tests (PFTs). ILD is one of the leading causes of death in systemic sclerosis patients. Major risk factors of ILD associated with SSc (SSc-ILD) include male sex, diffuse type of cutaneous SSc and presence of anti-Scl-70 antibodies.

Objectives: Taking into account that anti-Scl-70 antibody is an unfavorable predictor of ILD, we have assessed the time course of FVC and DLco in anti-Scl-70-positive and anti-Scl-70-negative patients.

Methods: It was a longitudinal study involving 77 pts with SSc-ILD (mean age was $46,2 \pm 13,4 ; 69 \%$ have limited subset of the disease; $93 \%$ were female). The mean duration of follow up was $58,9 \pm 11,4$ months. Pts. were investigated with HRCT twice (at first visit and at the end of the study) and according the CT-changes were divided into 3 groups: the 1st group (16 pts) with improvement; 2nd group (39 pts) without any changes and 3rd group (22 pts) with worsening of fibrosis. We evaluated the forced vital capacity (FVC), diffusing capacity of carbon monoxide (DLCO) in one year and in 5 years and anti-Scl-70 antibodies at the end of the study.

Results: In anti-Scl-70-negative patients the average FVC remained unchanged within a year $(91.4 \pm 17.4 \%$ и $91.6 \pm 17 \%$, respectively), however, within 5 years FVC significantly increased to $99.1 \pm 20 \%(p<$ 0.001), while in anti-Scl-70-positive patients the average FVC was lower at the baseline and remained virtually unchanged both 1 year and 5 years later $(85.4 \pm 17.3 \%$. $85.5 \pm 17$ и $86 \pm 21 \%$, respectively), as a result in 5 years' time the average FVC in anti-Scl-70-negative patients was significantly higher than in anti-Scl-70-positive patients $(p=0.009)$. At the baseline average DLco were below normal and were similar in anti-Scl-70-positive and anti-Scl-70-negative patients: $60 \pm 19 \%$ и $61.2 \pm$ $14.3 \%$ respectively $(p \quad 0,05)$. Within 1 year DLco significantly decreased in all patients, however anti-Scl-70-positive patients demonstrated more pronounced DLco decrease to $53.4 \pm 17.2 \%$ (p 0.0001), while in anti-Scl70 -negative patients it was less pronounced to $57.2 \pm 12.8 \% \quad(p<0.05)$, respectively. Within 5 years significant DLco decrease was found only in anti-Scl-70-positive patients: $53.9 \pm 16.4 \%(p<0.001)$.

The time courses of DLco in anti-Scl-70-positive and anti-Scl-70-negative patients by group are shown in Table 1 .

Significant DLco decrease over the 5-year period was observed in Group 2 and Group 3, and the lowest DLco $(<50 \%)$ were observed in Group 3.

Table 1:The. time course of DLco in anti-Scl-70-positive and anti-Scl-70-negative patients by group over the 5 year observation period

\begin{tabular}{llccccc}
\hline $\begin{array}{l}\text { Observation } \\
\text { period }\end{array}$ & \multicolumn{2}{c}{ Group 1 } & \multicolumn{2}{c}{ Group 2 } & \multicolumn{2}{c}{ Group 3 } \\
\cline { 2 - 7 } & $\begin{array}{l}\text { With anti- } \\
\text { Scl-70 } \\
(\mathrm{n}=4)\end{array}$ & $\begin{array}{c}\text { Without } \\
\text { anti-Scl-70 } \\
(\mathrm{n}=11)\end{array}$ & $\begin{array}{c}\text { With anti- } \\
\text { Scl-70 } \\
(\mathrm{n}=19)\end{array}$ & $\begin{array}{c}\text { Without } \\
\text { anti-Scl-70 } \\
(\mathrm{n}=17)\end{array}$ & $\begin{array}{c}\text { With anti- } \\
\text { Scl-70 } \\
(\mathrm{n}=17)\end{array}$ & $\begin{array}{c}\text { Without } \\
\text { anti-Scl-70 } \\
(\mathrm{n}=3)\end{array}$ \\
\hline $\begin{array}{l}\text { In 1 year } \\
(\mathrm{M} \pm \delta)\end{array}$ & $78.5 \pm 18$ & $61.5 \pm 18$ & $62 \pm 19$ & $64.1 \pm 11$ & $52 \pm 17$ & $64 \pm 1.8$ \\
$\begin{array}{l}\text { In 5 years } \\
(\mathrm{M} \pm \delta)\end{array}$ & $70 \pm 12.5$ & $57 \pm 14$ & $56 \pm 14$ & $61.5 \pm 9$ & $45 \pm 16$ & $52 \pm 7$ \\
$\mathrm{P}$ & $>0.05$ & $>0.05$ & $<0.05$ & $>0.05$ & $<0.05$ & $>0.05$ \\
\hline
\end{tabular}

Conclusion: Therefore, the presence of anti-Scl-70 antibodies was associated with significantly lower pulmonary function parameters specifically in pts with progressive ILD.

Disclosure of Interests: None declared

DOI: 10.1136/annrheumdis-2019-eular.7932

\section{AB0219 BIOMARKER EXPRESSION IN MONOCYTE SUBPOPULATIONS IN SSC PATIENTS}

Laiana Schneider ${ }^{1}$, Natalia Marcondes ${ }^{2}$, Vanessa $\mathrm{Hax}^{3,4}$, Isadora Moreira ${ }^{5}$, Carolina Yuka $^{5}$, Rafaella Romeiro ${ }^{5}$, Ricardo Xavier ${ }^{4}$, Rafael Chakr ${ }^{4}{ }^{1}$ Hospital de Clínicas de Porto Alegre, Serviço de Reumatologia, Porto Alegre, Brazil;

${ }^{2}$ Laboratório Zanol, Porto Alegre, Brazil; ${ }^{3}$ Hospital de Clínicas de Porto Alegre, Rheumatology, Porto Alegre, Brazil; ${ }^{4}$ Hospital de Clínicas de Porto Alegre, Porto Alegre, Brazil; ${ }^{5}$ School of Medicine, Porto Alegre, Brazil

Background: Systemic sclerosis (SSc) is a chronic autoimmune disease characterized by vasculopathy and fibrosis, which can be classified into diffuse cutaneous (dSSc) and limited cutaneous (ISSc) subtypes. Mono cytes are key agents in the pathophysiology of systemic autoimmune diseases, including systemic sclerosis (SSc). M1 cells (CD14++CD16-) represent a predominantly pro-inflammatory phenotype and $\mathrm{M} 2$ cells (CD14-/+CD16+/++) are more associated to an regulatory/pro-fibrotic phenotype.

Objectives: Our aim was to evaluate circulating blood monocyte subpopulations [classical (M1), intermediate and non-classical (M2)] and analyze the expression of CD163, CD169, CD206 and HLA-DR (function and activation monocytes receptors).

Methods: Fifty consecutive patients fulfilling the 2013 ACR/EULAR classification criteria for SSc were included in a cross-sectional study. Monocyte subpopulations were identified and characterized according to the expression of CD64, CD16, CD14, CD163, CD169, CD206 and HLA-DR. Thirty eight age- and sex-matched healthy individuals were recruited as a control group.

Results: SSc patients mean age was $57.2 \pm 12.8$ years (HC $55.2 \pm$ 11.4 ) and $94 \%$ were female. Limited form of disease was present in $72 \%$ of SSc patients and. SSc patients had an increased number of circulating peripheral blood monocytes compared to healthy subjects (table 1). Absolute counts of CD16+ (intermediary and non-classical) monocyte subpopulations were higher in SSc patients compared to $\mathrm{HC}$ [79.9 (53.4 $103.5) / \mathrm{mm}^{3}$ vs. $55.9(26.8-85.8) / \mathrm{mm}^{3}, \quad \mathrm{p}=0.003$. HLA-DR intensity of expression was higher in all monocyte subsets from ISSc and dSSc patients when compared to control. There was a higher percentage of classical [1.56 (0.84-2.98) vs. 0.68 (0.37-1.88); $\mathrm{p}=0.003$ ] and intermediate monocytes [15.9 (9.5-29.9) vs. $6.1 \quad(3.7-11.5) ; \mathrm{p}<0.001]$ with CD206 expression in SSc patients compared to $\mathrm{HC}$, and a higher percentage of CD169 expression in dSSc patients compared to control and ISSc groups $(p<0.01)$.

Table 1. Absolute value $\left(/ \mathrm{mm}^{3}\right)$ about monocytes subpopulations in all systemic sclerosis (SSc) patients compared to healthy controls (HC) and in limited (ISSc) and diffuse (dSSc) systemic sclerosis subtypes.

\begin{tabular}{|c|c|c|c|c|c|c|c|c|}
\hline $\begin{array}{l}\text { Monocytes } \\
\text { subpopulations }\end{array}$ & $\begin{array}{c}\text { SSc } \\
\text { patients } \\
(n=50)\end{array}$ & $\underset{(n=38)}{\mathrm{HC}}$ & $p^{*}$ & $\begin{array}{l}\text { ISSc } \\
(n=36)\end{array}$ & $\begin{array}{l}\text { dSSc } \\
(n=14)\end{array}$ & $\begin{array}{c}p^{*} \\
\text { (ISSc } \\
x \\
\text { dSSc) }\end{array}$ & $\begin{array}{c}p^{*} \\
(\text { ISSc } x \\
H C)\end{array}$ & $\begin{array}{c}p^{*} \\
(\mathrm{dSSc} \\
\times \mathrm{HC})\end{array}$ \\
\hline $\begin{array}{l}\text { Classical } \\
\text { monocytes }\end{array}$ & $\begin{array}{c}346.2 \\
(260.9- \\
450.8)\end{array}$ & $\begin{array}{l}209.8 \\
(146.1- \\
287.1)\end{array}$ & $<0.001$ & $\begin{array}{c}363.2 \\
(262.9- \\
451.8)\end{array}$ & $\begin{array}{c}326.5 \\
(231.2- \\
461.9)\end{array}$ & 0.779 & $<0.001$ & 0.003 \\
\hline $\begin{array}{l}\text { Intermediate } \\
\text { monocytes }\end{array}$ & $\begin{array}{l}38.2 \\
(24.6- \\
47.1)\end{array}$ & $\begin{array}{c}25.4 \\
(12.6- \\
41.2)\end{array}$ & 0.005 & $\begin{array}{c}38.5 \\
(24.7- \\
47.5)\end{array}$ & $\begin{array}{c}37.1 \\
(22.1- \\
49.1)\end{array}$ & 0.795 & 0.009 & 0.069 \\
\hline $\begin{array}{l}\text { Non-classical } \\
\text { monocytes }\end{array}$ & $\begin{array}{c}41.2 \\
(20.8- \\
58.3)\end{array}$ & $\begin{array}{c}28.3 \\
(11.5- \\
46.1)\end{array}$ & 0.006 & $\begin{array}{c}42.5 \\
(20.8- \\
69.0)\end{array}$ & $\begin{array}{l}37.1 \\
(20.8- \\
47.3)\end{array}$ & 0.310 & 0.005 & 0.201 \\
\hline
\end{tabular}

Data are shown as median (interquartile range- IQR). ${ }^{*}$ Mann-Whitney $U$ test

Conclusion: In our study, SSc patients show greater monocytes counts than $\mathrm{HC}$ with a predominantly regulatory/pro-fibrotic phenotype (M2). dSSc seems to be more associated to CD169 than ISSc.

\section{REFERENCES}

[1] Trombetta AC, Soldano S, Contini P, Tomatis V, Ruaro B, Paolino S, et al. A circulating cell population showing both $M 1$ and $M 2$ monocyte/macrophage surface markers characterizes systemic sclerosis patients with lung involvement. Respir Res. 2018.

[2] Lescoat A, Lecureur V, Roussel M, Sunnaram BL, Ballerie A, Coiffier G, et al. CD16-positive circulating monocytes and fibrotic manifestations of systemic sclerosis. Clin Rheumatol. 2017.

Disclosure of Interests: Laiana Schneider: None declared, Natalia Marcondes: None declared, Vanessa Hax: None declared, Isadora Moreira: None declared, carolina yuka: None declared, rafaella romeiro: None declared, Ricardo Xavier Consultant for: Abbvie, Pfizer, Novartis, Janssen, Lilly, Roche, Rafael Chakr: None declared 